\title{
METHOD OF PREDICTING FAVOURABLE INDUSTRIAL PRODUCTS
}

\begin{abstract}
Predicting favourable products is still challenging. It is influenced by dynamic customers' requirement changes and reduction of waste. An important problem is a simultaneous combination of customer satisfaction with environmental aspects. It resulted from a need to reduce the harmfulness of products and increasing the quality level of these products. Therefore, the aim is to propose a method to predict favourable products considering qualitative and environmental aspects. The method relies on predicting which product will be the most favourable for customer, and simultaneously will be the most environmentally friendly. Due to the uncertainty of decisions, the Grey Relational Analysis (GRA) was implemented in the proposed method. The GRA method is effective to any number of data, therefore the proposed method does not have limitations in numbers of qualitative and environmental criteria. The test was carried out based on harmful industrial products. It was fluorescent penetrants used in popular non-destructive testing.
\end{abstract}

Keywords: predict, GRA, quality, mechanical engineering, production engineering, decisions, sustainability.

\section{INTRODUCTION}

Sustainable development of products is one of the key enterprise actions. It relies on customizing the product to customers' expectations in a pro-environmental context (Mentel, Hajduk-Stelmachowicz, 2020; Ulewicz, Kleszcz, Ulewicz, 2021; Pacana, Siwiec, Bednarova, 2020; Siwiec, Pacana, 2021). In this aim, the organizations are looking for different solutions. Based on customers' requirements the new products are designed or existing products are modified (Okrah, Hajduk-Stelmachowicz, 2020; Siwiec, Pacana, 2021). For example, the popular House of Quality (HoQ) is used for it (Lee et al., 2019; Shi, Peng, 2020). Additionally, for the purpose to reduce inconsistencies in customer requirements the techniques with fuzzy Saaty scale are used. These methods were e.g.: Fuzzy Analytic Hierarchy Process (FAHP), or Fuzzy Technique for Order Preference By Similarity To Ideal Solution (FTOPSIS) (Ulewicz, Siwiec, Pacana, Tutak, Brodny, 2021; Siwiec, Bednarova, Pacana, 2020). However, these actions are still not enough. It has

\footnotetext{
${ }^{1}$ Dominika Siwiec, MSc, Rzeszow University of Technology, Rzeszów, 12 Powstańców Warszawy Ave., 35-959 Rzeszów; e-mail: d.siwiec@ @rz.edu.pl (corresponding author). ORCID: 0000-0002$-6663-6621$.

2 Stanislav Vandžura, Ing., Technical University of Kosice, Park Komenského 19, 04001 Košice, Slovakia; e-mail: stanislav.vandzura@ gmail.com. ORCID: 0000-0003-1850-7611.
} 
resulted from dynamic customer requirement changes and not beneficial climate changes (Hajduk-Stelmachowicz, 2017). Therefore, it is necessary to design the products in advance. The design should allow predicting expectation quality product level with simultaneously considering impact product on the environment (Siwiec, Pacana, 2021). Although quality of products and impact of products on the environment were predicted, these two aspects in a single method were not combined. Integration of qualitative and environmental aspects will be allowed to predict product which is expected by customers and environmentally friendly (Siwiec, Pacana, 2021; Siwiec, Bednarova, Pacana, Zawada, Rusko, 2019). These pro-environmental actions reduce waste and also are consistent with the idea of continuous product improvement. Therefore, the aim is to propose a method to predict favourable products considering qualitative and environmental aspects. The method is based on predicting which product will be the most beneficial for the customer and at the same time will have the least negative impact on the environment. The method relies on double apply Grey Relational Analysis (GRA) (Wang et al., 2015) to allow verification of any number of criteria (even four data). Test of the method was done for industrial products using in product quality controls.

\section{METHOD}

The method was to twice use the Grey Relational Analysis (GRA) (Ertugrul et al., 2016) to predict the most favourable quality product level which is environmentally friendly. The concept of the method relies on predicting the most favourable product considering qualitative-environmental criteria. The algorithm of the proposed method is presented in Figure 1.

The method stages in the next part of the study were characterized.

\subsection{Selecting of products}

The selection of products results from the entity's need who use this method. The number and kind of product are unlimited. The selection of products may have an effect e.g. product life cycle, or company' opinions.

\subsection{Determining of aim}

The aim should be to predict a satisfactory product. The satisfaction relates to achieving the expected product quality level, and this product will be environmentally friendly. To determine the aim it is useful to use the SMART method (Specific, Measurable, Achievable, Relevant, Time-bound) (Lawlor, Hornyak, 2012).

\subsection{Selecting of criteria}

The selection of criteria results from the needs of entity using the proposed method. Based on this, the product quality level considering environmental aspects will be determined. Therefore, the qualitative and environmental aspects should be selected. The qualitative criteria determine the product e.g. in the context of its use. The environmental criteria are criteria that characterize the product in turn of its impact on the environment. A total number of criteria (qualitative and environmental) should be equal to the maximum of 8 criteria (Mu, Pereyra-Rojas, 2017). The criteria should be selected during brainstorm (BM) and based on the product catalog (Jiao, Chen, 2006; Rossiter, Lilien, 1994; Siwiec, Pacana, 2021). 


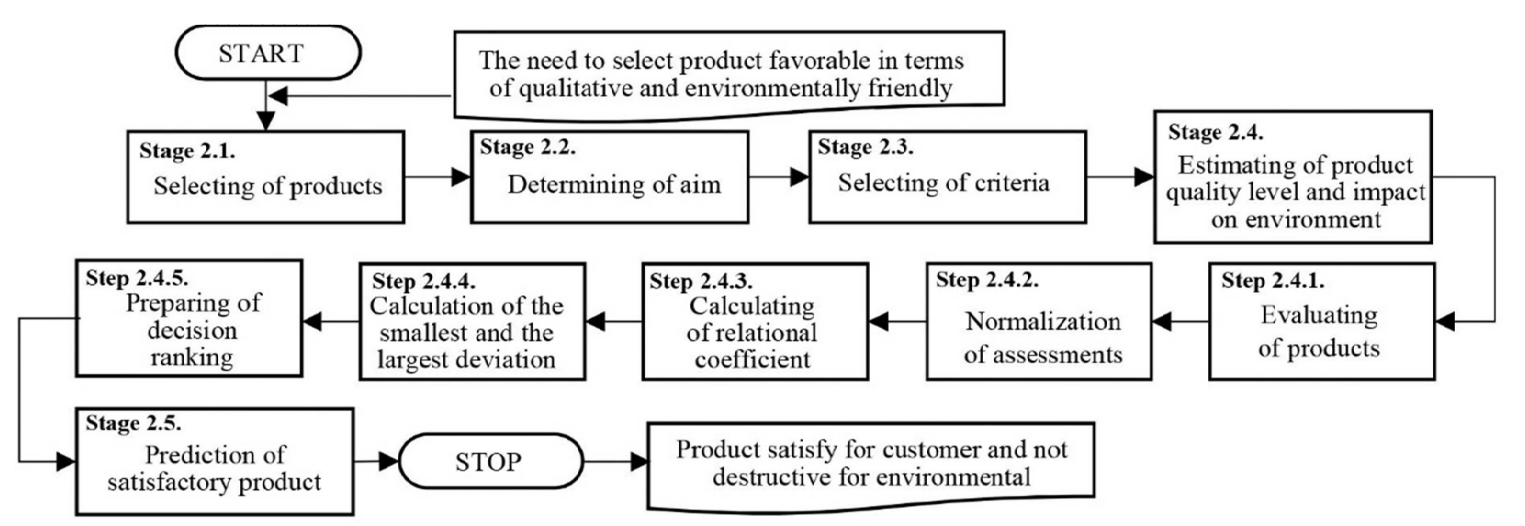

Figure 1. Algorithm of proposed method to predict satisfaction industrial products Źródło: Own study. 


\subsection{Estimating of product quality level and impact on environment}

The quality product level and its impact on the environment are estimating by Grey Relational Analysis (GRA) (Ertugrul et al., 2016; Javed et al., 2019; Wang et al., 2015). The choice of the GRA method resulted from its efficiency to predict the quality level and analyze in an uncertain (fuzzy) environment. Additionally, the GRA method is effective for the small number of criteria, i.e. even four data. The product quality level is estimating based on qualitative criteria. While the impact of products on the natural environment is estimating based on environmental criteria. It relies on twice apply the GRA method, i.e. separately for quality level and impact of product on the environment. This is presented in five main steps.

\section{Step 2.4.1. Evaluating of products}

The evaluation of products is realized in two decision matrices (M). In the first matrix $\mathrm{M}$, the products are evaluating based on qualitative criteria. In the second matrix $\mathrm{M}$, the products are evaluating based on environmental criteria. For this purpose the formula (1) is used (Ertugrul et al., 2016; Javed et al., 2019; Wang et al., 2015):

$$
\mathrm{M}=\mathrm{m}_{\mathrm{i}} \times \mathrm{n}_{\mathrm{j}}
$$

where: $\mathrm{m}$ - product, $\mathrm{n}$ - criterion, $\mathrm{i}, \mathrm{j}-1,2, \ldots, \mathrm{n}$.

The matrices are filled by assessments from 1 to 5 , where 5 - the most favourable product for a given criterion, 1 - the least favourable product for a given criterion.

\section{Step 2.4.2. Normalization of assessments}

The normalization of assessments relies on the transformation of assessments from $\mathrm{M}$ matrix to values in the range from 0 to 1 . For assessments of product qualitative criteria, formula (2) is used, because the higher the rating, the more favourable the criterion is in terms of the product quality level. In turn, for assessments of environmental criteria, formula (3) is used, because the lower the rating, the lower the environmental impact (Ertugrul et al., 2016; Javed et al., 2019; Wang et al., 2015):

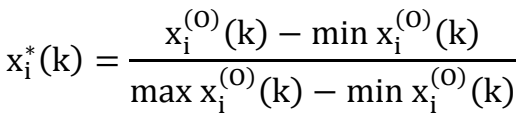

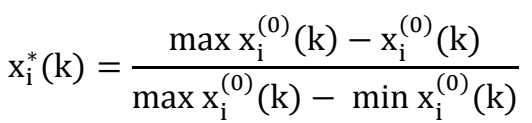

where: $x_{0}^{(O)}(k)$ - original sequence, $x_{i}^{(O)}(k)$ - comparison sequence, $i=1,2, \ldots, m$; $k=1,2, \ldots, n ; \mathrm{m}-$ alternative (i.e. product), $\mathrm{n}-$ criterion.

\section{Step 2.4.3. Calculating of relational coefficient}

The third step is calculating of Grey relational coefficient. This coefficient is calculated separately for qualitative and environmental criteria. For this purpose, the formula (4) is used (Ertugrul et al., 2016; Javed et al., 2019; Wang et al., 2015): 


$$
\begin{gathered}
\gamma\left[\mathrm{x}_{0}^{*}(\mathrm{k}), \mathrm{x}_{\mathrm{i}}^{*}(\mathrm{k})\right]=\frac{\Delta_{\min }+\xi \Delta_{\max }}{\Delta_{0 \mathrm{i}}(\mathrm{k})+\xi \Delta_{\max }}, \quad 0<\gamma\left[\mathrm{x}_{0}^{*}(\mathrm{k}), \mathrm{x}_{\mathrm{i}}^{*}(\mathrm{k})\right] \leq 1 \\
\Delta_{0 \mathrm{i}}(\mathrm{k})=\left|\mathrm{x}_{0}^{*}(\mathrm{k})-\mathrm{x}_{\mathrm{i}}^{*}(\mathrm{k})\right|
\end{gathered}
$$

where: $\Delta_{0 i}(k)$ - sequence of deviations between original sequence $x_{0}^{*}(k)$ and comparison sequence $x_{i}^{*}(k)$.

In turn, the coefficient $\boldsymbol{\xi}$ from formula (2) has value [0, 1]. Most often it is assumed that $\boldsymbol{\xi}=0.5$ (Ertugrul et al., 2016; Javed et al., 2019; Wang et al., 2015).

\section{Step 2.4.4. Calculation of the smallest and the largest deviation}

The smallest and the largest deviation are calculated for relational coefficient values for qualitative and environmental criteria. The smallest deviation is calculated from formula (5), while the largest deviation is calculated from formula (6) (Ertugrul et al., 2016; Javed et al., 2019; Wang et al., 2015):

$$
\begin{gathered}
\Delta_{\max }=\max _{\forall \mathrm{j} \in \mathrm{i}} \max _{\forall \mathrm{k}}\left|\mathrm{x}_{0}^{*}(\mathrm{k})-\mathrm{x}_{\mathrm{j}}^{*}(\mathrm{k})\right| \\
\Delta_{\min }=\min _{\forall \mathrm{j} \in \mathrm{i}} \min _{\forall \mathrm{k}}\left|\mathrm{x}_{0}^{*}(\mathrm{k})-\mathrm{x}_{\mathrm{j}}^{*}(\mathrm{k})\right|
\end{gathered}
$$

\section{Step 2.4.5. Preparing of decision ranking}

According to the GRA method, product quality level and its impact on the natural environment are estimating based on grey relation assessment. It is necessary to separately estimate the product quality level and its impact on the environment. In this aim, the weighted sum of Grey coefficients is estimating by formula (7) (Ertugrul et al., 2016; Javed et al., 2019; Wang et al., 2015):

$$
\gamma\left(\mathrm{x}_{0}^{*}, \mathrm{x}_{\mathrm{i}}^{*}\right)=\sum_{\mathrm{k}=\mathrm{i}}^{\mathrm{n}} \beta_{\mathrm{k}} \gamma\left[\mathrm{x}_{0}^{*}(\mathrm{k}), \mathrm{x}_{\mathrm{i}}^{*}(\mathrm{k})\right], \quad \text { where }: \gamma\left(\mathrm{x}_{0}^{*}, \mathrm{x}_{\mathrm{i}}^{*}\right)=\mathrm{q}_{\mathrm{i}}
$$

where: $q$ - product quality level or impact of product on natural environment, $\mathrm{i}-1,2, \ldots, \mathrm{n}$.

The sum of product quality level values or impact on the natural environment should be equal to 1 (8) (Ertugrul et al., 2016; Javed et al., 2019; Wang et al., 2015):

$$
\sum_{\mathrm{k}=1}^{\mathrm{n}} \beta_{\mathrm{k}}=1
$$

where: $\gamma\left(x_{0}^{*}, x_{i}^{*}\right)$ - grey relational assessment, i.e. correlation level between original and comparison sequence.

Consequently, two ranks are obtained. The first ranking is determining product quality level considering qualitative criteria. The maximum value is the first position in the ranking, i.e. the product the most satisfied in terms of quality. The second ranking is determining the impact of products on the environment considering environmental criteria. The maximum value is the first position in the ranking, i.e. the product the most negative (harmful) for the 
environment. The minimum value is the last position in the ranking, i.e. the product the least negative (harmful) for the environment.

\subsection{Prediction of satisfactory product}

At this stage of the method, the satisfactory product is predicted, i.e. the product the most favourable by qualitative and environmentally friendly. The most favourable product has the first position in qualitative criteria ranking and the first position in environmental criteria ranking.

\section{RESULTS AND DISCUSSION}

Test of the method was carried out based on fluorescent penetrants using in popular nondestructive testing (NDT). These penetrants were used in one of the Podkarpacie enterprises to control products from the aviation and motorize industries. In the enterprise, important was to achieve customers' satisfaction by simultaneously reduce harmful of these products on natural environment. Therefore, it was considered justified to apply the proposed method.

According to first stage of the method, the products to verify were selected. There were six penetrant from brands: Magnaflux, Chemetall, and Sherwin, which was using to test quality of product. The characteristic of products were presented in publicly available safety data sheets for these products. To test of the method these penetrants were marked randomly and conventionally from P1 to P6.

Next, in second stage of the method, the aim of the analysis was determined. The purpose was to predict satisfactory fluorescent penetrant to achieve product with expected quality level and environmentally friendly.

Then, as indicated in third step, the qualitative and environmental criteria of penetrants were selected. The criteria were selected during brainstorm and based on product catalogue. The qualitative criteria were: sensitivity level, drying time after penetration, density and viscosity. However, the environmental criteria were: health, rafined oil, reactivity and flashpoint.

According to fourth stage of the method, the penetrant quality level and their impact on environment were estimated. The Grey Relational Analysis (GRA) was used for it. In the first stage, fluorescent penetrants were separetly assessmented in turn of qualitative and eivornmental criteria. For that two $\mathrm{M}$ matrices were prepared (Table 1).

Following from second step of the method, assessments from qualitative and environmental criteria form $\mathrm{M}$ matrices were normalized. The formulas (2-3) were used for that. Results are shown in Table 2.

Then, according to third stage of the method, the Grey Relational Coefficient were calculated. It was assumed coefficient equal to $\boldsymbol{\xi}=0.5$. Next, in fourth stage, the minimum and maximum deviation were calculated. These calculation were based on values of relational coefficient for qualitative end environmental criteria. Results is shown in Table 3.

In fifth step of the method, two rankings for qualitative and environmental criteria were created. The first ranking determines the product quality level considering qualitive criteria. The second ranking determines the impact of product on environmental considering environmental criteria. Results are shown in Table 4. 
Table 1. Matrix of qualitative and environmental criteria

\begin{tabular}{|c|c|c|c|c|c|}
\hline \multicolumn{2}{|c|}{$\begin{array}{l}\text { Qualitative } \\
\text { criteria }\end{array}$} & Sensitivity level & $\begin{array}{l}\text { Drying time after } \\
\text { penetration }\end{array}$ & Density & Viscosity \\
\hline \multirow{6}{*}{ 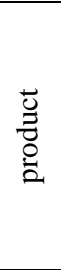 } & $\mathrm{P} 1$ & 5 & 4 & 3 & 3 \\
\hline & $\mathrm{P} 2$ & 4 & 4 & 3 & 4 \\
\hline & $\mathrm{P} 3$ & 4 & 4 & 4 & 3 \\
\hline & $\mathrm{P} 4$ & 4 & 3 & 2 & 2 \\
\hline & P5 & 3 & 2 & 3 & 2 \\
\hline & P6 & 3 & 4 & 3 & 3 \\
\hline \multicolumn{2}{|c|}{$\begin{array}{l}\text { Environmental } \\
\text { criteria }\end{array}$} & Health & Rafined oil & Reactivity & Flash-point \\
\hline \multirow{6}{*}{$\begin{array}{l}\stackrel{\breve{O}}{0} \\
\stackrel{0}{0}\end{array}$} & $\mathrm{P} 1$ & 3 & 2 & 3 & 4 \\
\hline & $\mathrm{P} 2$ & 3 & 2 & 2 & 3 \\
\hline & $\mathrm{P} 3$ & 2 & 1 & 2 & 3 \\
\hline & $\mathrm{P} 4$ & 3 & 2 & 3 & 3 \\
\hline & P5 & 3 & 2 & 2 & 4 \\
\hline & P6 & 2 & 1 & 1 & 2 \\
\hline
\end{tabular}

Source: Own study.

Table 2. Normalized assessments of qualitative and environmental criteria

\begin{tabular}{|c|c|c|c|c|c|}
\hline \multicolumn{2}{|c|}{$\begin{array}{l}\text { Qualitative } \\
\text { criteria }\end{array}$} & Sensitivity level & $\begin{array}{l}\text { Drying time after } \\
\text { penetration }\end{array}$ & Density & Viscosity \\
\hline \multirow{6}{*}{$\begin{array}{l}\bar{U} \\
\overline{0} \\
:\end{array}$} & $\mathrm{P} 1$ & 1,00 & 1,00 & 0,50 & 0,50 \\
\hline & $\mathrm{P} 2$ & 0,50 & 1,00 & 0,50 & 1,00 \\
\hline & P3 & 0,50 & 1,00 & 1,00 & 0,50 \\
\hline & $\mathrm{P} 4$ & 0,50 & 0,50 & 0,00 & 0,00 \\
\hline & P5 & 0,00 & 0,00 & 0,50 & 0,00 \\
\hline & P6 & 0,00 & 1,00 & 0,50 & 0,50 \\
\hline \multicolumn{2}{|c|}{$\begin{array}{l}\text { Environmental } \\
\text { criteria }\end{array}$} & Health & Rafined oil & Reactivity & Flash-point \\
\hline \multirow{6}{*}{$\begin{array}{l}\overline{0} \\
\tilde{z} \\
0 \\
0\end{array}$} & $\mathrm{P} 1$ & 1,00 & 1,00 & 1,00 & 1,00 \\
\hline & $\mathrm{P} 2$ & 1,00 & 1,00 & 0,50 & 0,50 \\
\hline & P3 & 0,00 & 0,00 & 0,50 & 0,50 \\
\hline & $\mathrm{P} 4$ & 1,00 & 1,00 & 1,00 & 0,50 \\
\hline & P5 & 1,00 & 1,00 & 0,50 & 1,00 \\
\hline & P6 & 0,00 & 0,00 & 0,00 & 0,00 \\
\hline
\end{tabular}

Source: Own study. 
Table 3. Relational coefficient values for qualitative end environmental criteria

\begin{tabular}{|c|c|c|c|c|c|}
\hline \multicolumn{2}{|c|}{$\begin{array}{l}\text { Qualitative } \\
\text { criteria }\end{array}$} & Sensitivity level & $\begin{array}{l}\text { Drying time after } \\
\text { penetration }\end{array}$ & Density & Viscosity \\
\hline \multirow{6}{*}{$\begin{array}{l}\bar{\circlearrowright} \\
\bar{\Xi} \\
:\end{array}$} & $\mathrm{P} 1$ & 1,00 & 1,00 & 0,50 & 0,50 \\
\hline & $\mathrm{P} 2$ & 0,50 & 1,00 & 0,50 & 1,00 \\
\hline & $\mathrm{P} 3$ & 0,50 & 1,00 & 1,00 & 0,50 \\
\hline & $\mathrm{P} 4$ & 0,50 & 0,50 & 0,33 & 0,33 \\
\hline & P5 & 0,33 & 0,33 & 0,50 & 0,33 \\
\hline & P6 & 0,33 & 1,00 & 0,50 & 0,50 \\
\hline \multicolumn{2}{|c|}{$\begin{array}{l}\text { Environmental } \\
\text { criteria }\end{array}$} & Health & Rafined oil & Reactivity & Flash-point \\
\hline \multirow{6}{*}{$\begin{array}{l}\tilde{0} \\
\stackrel{\Xi}{0} \\
\stackrel{0}{0}\end{array}$} & $\mathrm{P} 1$ & 1,00 & 1,00 & 1,00 & 1,00 \\
\hline & $\mathrm{P} 2$ & 1,00 & 1,00 & 0,50 & 0,50 \\
\hline & $\mathrm{P} 3$ & 0,33 & 0,33 & 0,50 & 0,50 \\
\hline & $\mathrm{P} 4$ & 1,00 & 1,00 & 1,00 & 0,50 \\
\hline & P5 & 1,00 & 1,00 & 0,50 & 1,00 \\
\hline & P6 & 0,33 & 0,33 & 0,33 & 0,33 \\
\hline
\end{tabular}

Source: Own study.

Table 4. Result of used the GRA method to determine qualitative and environmental criteria

\begin{tabular}{|c|c|c|c|c|}
\hline Products & \multicolumn{2}{|c|}{ Qualitative criteria - ranking } & \multicolumn{2}{c|}{ Environmental criteria - ranking } \\
\hline P1 & 0,75 & 1 & 1,00 & 5 \\
\hline P2 & 0,75 & 1 & 0,75 & 3 \\
\hline P3 & 0,75 & 1 & 0,42 & 2 \\
\hline P4 & 0,42 & 3 & 0,88 & 4 \\
\hline P5 & 0,38 & 4 & 0,88 & 4 \\
\hline P6 & 0,58 & 2 & 0,33 & 1 \\
\hline
\end{tabular}

Source: Own study.

On this stage it was concluded, the most favourable quality product level has three penetrants P1, P2, P3, which quality level on 0.75 level were determined. Although, in the context of impact these penetrans on environmental it was shown, that the most favourable is P6 penetrant. The most favourable was penetrant P6, because this penetrant has second place in ranking of qualitative criteria and the first place in ranking of environmental criteria. Accordance with ranking it is possible to predict of satisfaction from other penetrants. Therefore, the last choice of penetrant depends on entity using of the proposed method.

\section{CONCLUSIONS}

Sustainability development of products still is challenge. In this context the enterprises are tried to achieve customers' expectations by improvement existing products. Hence, in the era of unfavourable climate changes it is important also considering environmental 
aspects. Mainly problem is predicting of expected changes in products and impact of these changes on environment. Therefore, important is looking for different instruments supporting this process. Therefore, the aim was to propose a method to predict favourable products considering qualitative and environmental aspects. The method has relied on predicting which of product is the best for customers and simultaneously is friendly for environmental. The method was designed in the five main stages. Additionally, in the proposed method, the Grey Relational Analysis (GRA) was implemented, which is effective in a fuzzy (uncertain) decision environment. The method was tested based on harmful fluorescent penetrants. These products were used in popular non-destructive testing (NDT) in quality control. The six penetrants were analyzed. The penetrants based on qualitative and environmental criteria were verified. The qualitative criteria were: sensitivity level, drying time after penetration, density and viscosity. However, the environmental criteria were: health, rafined oil, reactivity and flash-point. After double applied Grey Relational Analysis it was possible to predict the most beneficial industrial product. It was product about favourable quality level and simultaneously the most favourable for the environment. It was shown the effectiveness of the method to predict beneficial qualitative-environmental decisions for industrial products. Hence, this method can be applied for any product, which prediction quality level considering environmental aspects is necessary.

\section{REFERENCES}

Ertugrul, I. et al. (2016). Grey Relational Analysis Approach in Academic Performance Comparison of University: A Case Study Of Turkish Universities. "European Scientific Journal”, 12.

Hajduk-Stelmachowicz, M. (2017). Organisational Eco-innovations in the Companies Located in the Podkarpackie Province - The Aspect of Costs. "Reseach Papers of Wroclaw University of Economics", 491.

Javed, S.A. et al. (2019). Systems Evaluation through New Grey Relational Analysis Approach: An Application on Thermal Conductivity - Petrophysical Parameters' Relationships. "Processes", 7. DOI: 10.3390/pr7060348.

Jiao, JX., Chen, CH. (2006). Customer requirement management in product development: A review of research issues. "Concurrent Engineering-Research And Applications", 14(3). DOI: $10.1177 / 1063293 X 06068357$.

Lawlor, K. B., Hornyak, M. J. (2012). Smart Goals: How The Application Of Smart Goals Can Contribute To Achievement Of Student Learning Outcomes. "Developments in Business Simulation and Experiential Learning" 39.

Lee, C. H., Chen, C. H., Lin, C. Y., Li, F., Zhao, X. J. (2019). Developing a Quick Response Product Configuration System under Industry 4.0 Based on Customer Requirement Modelling and Optimization Method. "Applied Sciences-Basel”, 9(23). DOI: 10.3390/ app9235004.

Luca, L. (2016). A new model of Ishikawa diagram for quality assessment, "IOP Conference Series Materials Science and Engineering”, 151, 1. DOI: 10.1088/1757-899X/161/1/ 012099.

Mentel, U., Hajduk-Stelmachowicz, M. (2020). Does standardization have an impact on innovation activity in different countries?. "Problems and Perspectives in Management", 18(4). DOI: 10.21511/ppm.18(4).2020.39. 
Mu, E., Pereyra-Rojas, M. (2017). Practical Decision Making [In:] Springer Briefs in Operations Research, Appendix A: Practical Questions Related to AHP Modeling; Springer Nature: Basel, Switzerland, 105-106.

Okrah, J., Hajduk-Stelmachowicz, M. (2020). Political stability and innovation in Africa. “Journal of International Studies", 11. DOI: 10.14254/2071-8330.2020/13-1/15.

Pacana, A., Siwiec, D., Bednárová, L. (2020). Method of Choice: A Fluorescent Penetrant Taking into Account Sustainability Crite-ria. "Sustainability" 12, 5854. DOI: 10.3390/ su12145854.

Rossiter, J., Lilien, G. (1994). New “Brainstorming” Principles. "Australian Journal of Management", 19, 1.

Shi, Y. L., Peng, Q. J. (2020). A spectral clustering method to improve importance rating accuracy of customer requirements in QFD. "International Journal Of Advanced Manufacturing Technology”, 107(5-6). DOI: 10.1007/s00170-020-05204-1.

Siwiec D., Pacana A. (2021). Method of improve the level of product quality. "Production Engineering Archives", 27(1). DOI: 10.30657/pea.2021.27.1.

Siwiec, D., Bednarova, L., Pacana, A. (2020). Metoda doboru penetrantów dla przemystowych badań nieniszczacych. „Przemyst Chemiczny”, 99(5). DOI: 10.15199/62.2020.5.18.

Siwiec, D., Bednarova, L., Pacana, A., Zawada, M., Rusko, M. (2019). Wspomaganie decyzji $w$ procesie doboru penetrantów fluorescencyjnych do przemystowych badań nieniszczacych. „Przemyst Chemiczny”, 98(10). DOI: 10.15199/62.2019.10.12.

Siwiec, D., Pacana, A. (2021). A Pro-Environmental Method of Sample Size Determination to Predict the Quality Level of Products Considering Current Customers' Expectations. "Sustainability" 13. DOI: 10.3390/su13105542.

Ulewicz, R., Kleszcz, D., Ulewicz, M. (2021). Implementation of Lean Instruments in Ceramics Industries. "Management Systems in Production Engineering", 29(3). DOI: 10.2478/ mspe-2021-0025.

Ulewicz, R., Siwiec, D., Pacana, A., Tutak, M., Brodny, J. (2021). Multi-Criteria Method for the Selection of Renewable Energy Sources in the Polish Industrial Sector. "Energies" 14. DOI: 10.3390/en14092386.

Wang F. et al. (2015). Capturing the key customer requirements for complex equipment design using Grey Relational Analysis. “Journal of Grey System”, 27(3).

DOI: 10.7862/rz.2021.mmr.20

The text was submitted to the editorial office: July 2021.

The text was accepted for publication: September 2021. 